\title{
Peningkatan Kemampuan Penalaran Statistis Siswa Sekolah Menengah Pertama Melalui Pembelajaran Kontekstual
}

\author{
THE IMPROVEMENT OF HIGH SCHOOL STUDENTS' REASONING ABILITY THROUGH \\ CONTEXTUAL LEARNING
}

\author{
Iyam Maryati \\ Pendidikan Matematika, Dosen STKIP Garut \\ Mahasiswa S3 Universitas Pendidikan Indonesia \\ maryati_iyam@yahoo.co.id
}

\begin{abstract}
Abstrak
Artikel ini menyajikan apa itu pembelajaran kontekstual dan apa saja karakteristiknya? Apa itu kemampuan penalaran statistis? Mengapa pembelajaran kontekstual dapat mengembangkan kemapuan penalaran statistis siswa Sekolah Menengah Pertama? Kemampuan penalaran statistis sangat penting dimiliki oleh siswa Sekolah Menengah Pertama, karena dengan kemampuan penalaranr statistis ini siswa dapat memiliki kompetensi dalam hal: 1) memahami informasiinformasi statistis yang tersurat maupun yang tersirat pada setiap permasalahan yang dihadapi. 2) Pemahaman yang baik terhadap bagaimana cara memilih, menyajikan, mererduksi, dan mempresentasikan data yang akan digunakan untuk menjawab permasalahan yang ada. 3) pemahaman dan penalaran yang baik terhadap proses statistis secara keseluruhan termasuk setiap perhitungan yang terlibat dalam proses tersebut. 4) pemahaman untuk memecahkan masalah secara statistis berdasarkan data yang ada, dan menginterprestasikannya dalam pengambilan keputusan yang dapat berlaku secara umum. Oleh karena itu untuk mengembangkan kemampuan penalaran statistis tersebut harus mempertimbangkan pendekatan pembelajaran yang digunakan untuk siswa Sekolah Menengah Pertama. Model pendekatan pembelajaran yang sesuai untuk siswa Sekolah Pertama salah satunya adalah pendekatan pembelajaran kontekstual (Contextual Teaching and Learning). Pendekatan pembelajaran kontekstual ini mengambil permasalahan-permasalahan dalam kehidupan seharihari atau permasalahan yang disimulasikan dengan dialog, diskusi,, tanya jawab, dan representasi. Aktivitas pengajaran kontekstual yang dikembangkan adalah: a) belajar berbasis masalah, b) belajar dengan multi konteks, c) belajar mandiri, d) penilaian otentik, dan e) masyarakat belajar.

Kata Kunci: Kemampuan Penalaran statistis, , Pendekatan Pembelajaran Kontekstual.
\end{abstract}

\begin{abstract}
This article presents a contextual learning what it is and what are its characteristics? What is the statistical reasoning skills? Why contextual learning can develop statistical reasoning Traffic junior secondary students? Reasoning ability is very important statistical owned by junior high school students, because of the ability of these statistical penalaranr students may have competence in terms of: 1) understand the statistical information expressed or implied in any problems faced. 2) A good understanding of how to choose, present, mererduksi, and present data that will be used to address existing problems. 3) understanding and reasoning that both the statistical process as a whole including any calculations involved in the process. 4) understanding to solve the problem of statistically based on existing data, and interpret it in decision-making that can be applied generally. Therefore, to develop the statistical reasoning skills should consider
\end{abstract}


learning approach used for junior secondary students. Model learning approach that is appropriate for school students first one of which is a contextual learning approach (Contextual Teaching and Learning). This contextual learning approach to take problems in daily life or simulated problems with dialogue, discussion "question and answer, and representation. Contextual teaching activities developed are: a) problem-based learning, b) learning with multi context, c) self-learning, d) authentic assessment, and e) a learning society.

Keyword: Reasoning ability statistical,, Contextual Learning Approach.

\section{Pendahuluan}

Kemampuan penalaran statistis merupakan kemampuan untuk memahami informasi-informasi yang ada dalam kehidupan keseharian berdasarkan datadata statistic, kemampuan untuk memjawab permasalahan dengan baik berdasarkan data yang ada dengan cara yang berbeda dan memperoleh hasil yang tidak jauh berbeda. Kemampuan penalaran statistis juga data berarti kemampuan untuk memahami dengan baik bagaimana cara memilih, menyajikan, mereduksi, dan mempresentasikan data yang akan digunakan untuk permasalahan yang ada. Kemampuan ini sangat penting untuk dikembangkan pada siswa sekolah menengah pertama. Karena perkembangan kognitif (berpikir) pada anak saat berada di sekolah menengah pertama (SMP) merupakan tahap formal operasional, dikemukakan pandangan dari Piaget, Vigotksy, dan para ahli psikologi pemprosesan informasi (informationprocessing theory) menyatakan bahwa aspek kognitif meliputi fungsi intelektual seperti pemahaman, pengetahuan dan ketrampilan berpikir. Untuk siswa SMP, perkembangan kognitif utama yang dialami adalah formal operasional, yang mampu berpikir abstrak dengan menggunakan simbol-simbol tertentu atau mengoperasikan kaidah-kaidah logika formal yang tidak terikat lagi oleh objekobjek yang bersifat konkrit, seperti peningkatan kemampuan analisis, kemampuan mengembangkan suatu kemungkinan berdasarkan dua atau lebih kemungkinan yang ada, kemampuan menarik generalisasi dan inferensasi dari berbagai kategori objek yang beragam. Untuk mengembangkan kemampuan statistis siswa sangat penting untuk mempertimbangkan pendekatan pembelajaran. Salah satunya dengan pendekatan pembelajaran kontekstual.

Apa itu pembelajaran kontekstual dan apa saja karakteristiknya? Apa itu kemampuan penalaran statistis? Mengapa pembelajaran kontekstual dapat mengembangkan kemampuan penalaran statistis siswa Sekolah Menengah Pertama?. Tulisan dalam artikel ini akan berusaha untuk memaparkan dan menjawab atas pertanyaan-pertanyaan yang diajukan tersebut.

Pembelajaran kontekstual telah berkembang di negara-negara maju dengan berbagai nama. Di negeri Belanda berkembang dengan nama Realistic Mathematics Education (RME) yang menjelaskan bahwa pembelajaran 
matematika harus dikaitkan dengan kehidupan nyata siswa. Di Amerika Serikat berkembang dengan nama Contextual Teaching and Learning (CTL) yang intinya membantu guru untuk mengaitkan materi pelajaran dengan kehidupan nyata dan memotivasi siswa untuk mengaitkan pengetahuan yang dipelajarinya dengan kehidupan mereka. Sementara itu di Michigan juga berkembang dengan Connected Mathematics Project (CMP) yang bertujuan mengintegrasikan ide matematika ke dalam konteks kehidupan nyata dengan harapan siswa dapat memahami apa yang dipelajarinya dengan baik dan mudah.

Defenisi pembelajaran yang ditulis oleh Johnson (2002: 25) merumuskan pengetahuan CTL sebagai berikut:

"The CTL is an educational process that aims to helps students see meaning in the academic material they are studying by connecting academic subjects with the context of their daily lives, that is, with the context of their personal, social, and cultural circumstances. To achievethis aim, the system encompasses the following eight components: making meaningful connections, doing significant work, selfregulated learning, collaborating, sritical and creative thinking, nurturing the individual, reaching high standards, using authentic assessment".

Kutipan di atas mengandung arti bahwa system CTL merupakan suatu proses pendidikan yang bertujuan membantu siswa melihat makna dalam bahan pelajran yang mereka pelajari dengan cara menghubungkannya dengan konteks sehari-hari, yaitu dengan konteks lingkungan pribadi, sosial dan budaya. Untuk mencapai tujuan tersebut, sistem CTL akan menuntun siswa melalui delapan prinsip utama CTL yaitu : melakukan hubungan yang bermakna, mengerjakan pekerjaan yang berarti, mengatur cara belajar sendiri, bekerja sama, berpikir kritis dan kreatif, memelihara/ merawat pribadi siswa, mencapai standar yang tinggi, dan menggunakan asesmen autentik.

Sedangkan The Washington State Consortium for Contextual Teaching and Learning (Nurhadi: 2002:12) merumuskan defenisi CTL sebagai berikut:

"Contextual Teaching is teaching that enables students to reinforce, expand, and apply their academic knowledge ands skills in a variety of in schooland out-of- school settings in order to solve simulated or realword problems. Contextual learning occurs when students apply and experience what is being taught referencing real problem asosciated with their roles and responsibilities as family numbers, citizens, students, and workers. Contextual teaching and learning emphasizes higherlevel thinking knowledge transfer across academic disciplines, and collecting, analyzing and synthesizing information and data from multiple sources and viewpoints".

Terjemahan bebasnya, pengajaran kontekstual adalah pengajaran yang memungkinkan siswa memperkuat, memperluas, dan menerapkan pengetahuan dan keterampilan 
akademisnya dalam berbagai bidang baik di sekolah maupun luar sekolah untuk memecahkan seluruh persoalan yang ada dalam dunia nyata. Pembelajaran kontekstual terjadi ketika siswa menerapkan dan mengalami apa yang diajarkan dengan mengacu pada masalahmasalah yang real yang berasosiasi dengan peranan dan tanggung jawab mereka sebagai anggota keluarga, anggota masyarakat, siswa, dan selaku pekerja. Pengajaran dan pembelajaran kontekstual menekankan berpikir tingkat tinggi, transfer pengetahuan melalui disiplin ilmu, dan mengumpulkan, menganalisis dan mensitesiskan informasi dan data dari berbagai sumber dan sudut pandang.

Dengan demikian, pernyataan ringkas mengenai pengertian pembelajaran kontekstual dari penulis, pembelajaran kontekstual (Contextual Teaching and Learning) adalah konsep belajar yang menghadirkan dunia nyata kedalam kelas dan mendorong siswa membuat hubungan antara pengetahuan yang dimilikinya dengan penerapannya dalam kehidupan sehari-hari, siswa memperoleh pengetahuan dan keterampilan dari konteks, dan dari proses mengkonstruksi sendiri sebagai bekal untuk memecahkan masalah dalam kehidupannya sebagai anggota masyarakat.

Dari uraian di atas dapat disimpulkan bahwa pembelajaran kontekstual merupakan konsep belajar yang membantu guru mengaitkan antara materi yang diajarkan dengan situasi nyata siswa. Selain itu kontekstual membantu para siswa menemukan makna dalam pelajaran mereka dengan cara menghubungkan materi dengan konteks kehidupan keseharian. Mereka membuat hubunganhubungan penting yang menghasilkan makna dengan melaksanakan pembelajaran yang diatur sendiri, bekerja sama, berpikir kritis dan kreatif, menghargai orang lain, mencapai standar tinggi, dan berperan serta dalam tugastugas penilaian autentik.

Pembelajaran matematika yang kontekstual mempunyai beberapa ciri khas sebagai berikut (Nur M 2000 : 2):

1. Diajukannya masalah kontekstual untuk dipecahkan atau diselesaikan oleh siswa pada awal proses pembelajaran.

2. Dikembangkannya cara, alat atau model matematis (misalnya: gambar, grafik, tabel, model benda tertentu) untuk memperoleh jawaban informal dari masalah. Jawaban informal siswa diistilahkan sebagai matematika informal. Cara, alat atau model itu berfungsi sebagai jembatan antara dunia real dan dunia abstrak untuk mewujudkan terjadinya proses matematisasi horisontal. Proses matematisasi horisontal adalah proses diperolehnya matematika informal oleh siswa.

3. Terjadi interaksi antara guru dan siswa atau antara siswa dan siswa atau antara siswa-pakar dalam suasana demokratif berkenaan dengan penyelesaian. 
4. Ada keseimbangan antara terjadinya proses matematisasi horisontal atau diperolehnya matematika informal oleh siswa dan proses matematika vertikal atau proses pembahasan matematika formal (secara simbolik dan abstrak) yang dimotori oleh guru atau orang lain (dapat salah satu siswa) yang dipandang pakar. Ini berarti ada kesempatan yang cukup bagi siswa untuk menemukan, menyelidiki atau memecahkan pesoalan dalam rangka mencari jawaban persoalan sebelum sampai pada tahap pembahasan matematika formal.

5. Ada kesempatan yang cukup bagi siswa untuk merefleksi, menginterpretasi dan menginternalisasi hal-hal yang telah dipelajariatau dihasilkan oleh siswa selama proses belajar.

\section{KAJIAN TEORI}

Penalaran merupakan proses berpikir yang bertolak dari pengamatan panca indera (pengamatan empirik) yang menghasilkan sejumlah konsep dan pengertian. Sehingga proses bernalar didasarkan pada pengamatan yang sejenis juga akan terbentuk proposisi-proposisi yang sejenis, Sejumlah proposisi yang diketahui atau dianggap benar, orang menyimpulkan sebuah proposisi baru yang sebelumnya tidak diketahui. Premis merupakan proposisi yang dijadikan dasar penyimpulan sedangkan dalam penalaran, hubungan antara premis dan konklusi disebut konsekuensi.

Penalaran statistis didefinisikan sebagai alasan cara orang dengan ide-ide statistik dan memahami informasi statistik, Garfield and Chance (2000). Sedangkan penalaran statistis sebagai cara bekerja dengan konten staatistik (mengingat, mengakui, dan membedakan diantara konsep-konsep statistik) dan keterampilan menggunakan konsep-konsep statistik dalam tahapan pemecahan maslah tertentu. Penalaran statistik sebagai proses menggunakan konten statistik melalui tiga tahapan meliputi: 1) Pemahaman yaitu melihat masalah sebagai yang sama dalam satu kelas; 2) Perencanaan dan eksekusi, yaitu menerapkan metode yang tepat untuk pemecahan masalah; 3) Evaluasi dan interprestasi, yaitu menafsirkan hasil yang berkaitan dengan masalah orisinil (asli), Chervany, Benson, dan lyer (dalam Garfield, 2002). Ben-Zvi dan Garfield (2004) menyatakan bahwa penalaran statistis melibatkan interprestasi keputusan berdasarkan himpunan data, representasi data, atau ringkasan data statistik. Berdasarkan beberapa defenisi di atas dapat dinyatakan bahwa penalaran statistis merupakan cara atau metode untuk mengajukan argumen dan penarikan kesimpulan logis dengan menggunakan ide-ide statistik yang bersumber dari informasi statistik.

Beberapa hasil penelitiaan yang berupaya mengembangkan penalaran statistis pada siswa, diantaranya Rosman 
and Cance (2001) mengembangkan penalaran statistis siswa tentang data dan distribusi data statistik dengan menggunakan rancangan khususke dalam workshop statistika. Sebagai hasilnya penggunaan rancangan tersebut dapat membantu mengembangkan penalaran statistis siswa tentang data dan distribusi data statistik. Sedangkan Delmas et al (2001) mengembangkan kemampuan penalaran statistis siswa tentang distribusi sampling.

Berkaitan dengan kemampuan penalaran statistik, Dasari (2009) mengemukakan bahwa kemampuan penalaran ststistis adalah kemampuan menarik kesimpulan dan memberi penjelasan berdasarkan orientasi data dengan memperhatikan prosedur terstruktur, tidak terstruktur, dan konsep statistik serta memberikan komentar kritis terhadap suatu proses atau hasil statistika. Olani et all (2011) mengatakan bahwa kemampuan penalaran statistis mengacu pada kemampuan untuk memahami dan mengintegrasikan data dan membuat keputusan berdasarkan konteks statistik.

Mengidentifikasi kemampuan penalaran statistis pada siswa (Garfield, 2002) menguraikan contoh dalam materi statistika untuk mengembangkan kemampuan penalaran statistis yaitu:

1. Penalaran tentang data adalah mengenali dan mengkategorikan data sebagai data kuantitatif atau kualitatif, diskrit atau kontinu, dan mengetahui bagaimana jenis data yang sesuai untuk ditampilkan pada tabel atau diagram.

2. Penalaran tentang representasi data adalah memahami cara penarikan sampel yang mewakili suatu populasi, bagaimana cara memodifikasi grafik untuk mewakili suatu data; mampu melihat berdasarkan tanda-tanda secara acak dari suatu distribusi tenttang karakteristik umumnya seperti: bentuk, kecenderungan, ukuran pusat, dan ukuran penyebaran.

3. Penalaran tentang ukuran statistik adalah memahami ukuran gejala pusat, ukuran letak, dan ukuran sebaran data, menggambarkan hal yang berbeda tentang suatu data; mengetahui mana yang terbaik untuk digunakan dalam kondisi yang berbeda, mengetahui mengapa rekapitulasi untuk prediksi suatu data ukuran sampel besar lebih akurat dibandingkan sampel kecil; mengetahui mengapa rekapitulasi ukuran pusat dan penyebaran berguna untuk membandingkan data.

4. Penalaran tentang peluang adalah memahami secra benar ide-ide keacakan (random), peluang, dan probabilitas untuk membuat keputusan tetang peristiwa yang tidak pasti, mengetahui kejadian yang berbeda dapat ditentukan dengan menggunakan metode yang berbeda.

5. Penalaran tentang sampel adalah mengetahui hubungan sampel dengan ppopulasi dan apa yang dapat 
disimpulkan dari sampel, mengetahui mengapa sampel dipilih dengan baik akan lebih akurat mewakili populasi dan mengapa ada cara untuk memilih sampel yang membuatnya representatif dari populasi.

6. Penalaran tentang asosiasi adalah mengetahui cara menilai dan menafsirkan hubungan antara dua variabel tidak berarti bahwa salah satu menyebabkan yang lainnya.

Menurut Garfield (2002) sebuah model penalaran statistis memiliki lima level dan disusun secara hierarkis sebagai berikut:

\section{Penalaran Idiosyncratic}

Mengetahui simbol dan istilah statistika, namun belum memahami penggunaannya. Sebagai contoh, siswa telah mempelajari rerata, median, dan simpangan baku sebagai ukuran ringkasan suatu data, tetapi penggunaannya tidak benar, seperti membandingkan rata-rata dengan standar simpangan baku.

\section{Penalaran verbal}

Mempunyai pemahaman verbal dari beberapa konsep, namun belum dapat mengaplikasikannya. Contohnya, siswa dapat mendefenisikan suatu konsep dengan tepat namun pemahaman konsep tersebut secara utuhtidak dimilikinya, seperti mengapa rerata lebih besar dari median dalam distribusi skewed

\section{Penalaran Transitional}

Mempunyai kemampuan untuk mengidentifikasi secara benar beberapa konsep statistika, namun pemahaman dari konsep-konsep tersebut tidak terintegrasi secara utuh/ menyeluruh. Sebagai contoh, pemahaman mengenai konsep ukuran sampel, semakin besar ukuran sebuah sampel maka semakin sempit interval kepercayaan yang dihasilkan, semakin kecil standar error maka semakin sempit pula interval kepercayaan yang dihasilkan.

\section{Penalaran Prosedural}

Mempunyai kemampuan untuk mengidentifikasi secara benar konsepkonsep statistika, namun aplikasi dari konsep itu belum terintegrasi secara utuh. Contohnya, seseorang yang memiliki kemampuan untuk menghitung korelasi secara benar namun belum mampu menjelaskan secara utuh mengapa digunakan konsep tersebut.

\section{Penalaran Proses Terintegrasi}

Mempunyai pemahamanlengkap tentang konsep-konsep statistika, hubungan dengan konsep lain dan aplikasinya, serta mampu memberikan penjelasan tentang suatu konsep dengan menggunakan kalimat sendiri. Contohnya, seseorang yang dapat menjelaskan secara benar arti dan selang kepercayaan 95\% dalam kaitannya dengan proses sampling.

\section{Pembahasan}

Dalam pembelajaran kontekstual, diperlukan adanya interaksi antara siswa dengan siswa, siswa engan guru, dan siswa-guru dengan materi ajar. Dalam hal ini diperoleh kemaksimalan pemahaman siswa, dan siswa diberi kesempatan mengkomunikasikan hasil olahan pemikiran kepada temannya. Di samping rasa percaya diri siswa dibangun juga budaya bersosialisasi di antara siswa, 
siswa-siswa saling menghargai dan lebih mandiri. Menurut Garfield (2002), pembelajaran statistika dengan menggunakan pendekatan kontekstual mampu mengkonstruksi pengetahuan yang dimiliki siswa menjadi pola-pola yang bermakna dan berguna sehingga memuliki pemahaman dan keterampilan dalam menghadapi suatu persoalan.

Di dalam pembelajaran kontekstual, siswa didorong untuk mencari dan menemukan hubngan untuk antara ide-ide abstrak dengan aplikasinya dalam kehidupan sehari-hari. Siswa menginternalisasi konsep melalui penemuan, penguatan, dan keterhubungan. Pembelajaran kontekstual menghendaki kerja dalam tim baik di kelas maupun laboratorium. Sehinggga pembelajaran statistika kontekstual adalah pembelajaran statistika dengan pendekatan kontekstual dimana siswa didorong untuk mengaitkan materi statistika yang dipelajari dalam kehidupan nyata siswa sehari-hari, baik di lingkungan keluarga, sekolah atau masyarakat dengan tujuan untuk menemukan makna materi tersebut bagi kehidupannya. Proses pembelajaran berlangsung alamiah dalam bentuk kegiatan siswa bekerja dan mengalami, bukan hanya sekedar mentransfer pengetahuan dari guru kepada siswa. Selanjutnya Lovett (2001) berdasarkan hasil penelitiannya mengemukakan bahwa untuk memahami dan meningkatkan penalaran statistis siswa, dilakukan dengan mengintegrasikan tiga pendekatan yaitu pendekatan studi teoritis, studi empiris, dan penelitian berbasis kelas. Hubungannya tiga pendekatan tersebut, Lovett menyarankan sebuah model pembelajaran lingkungan untuk membantu siswa mengembangkan penalaran statistis secara tepat yang akan dievaluasi dalam penelitian masa depan.

Untuk dapat mengimplementasikan pembelajaran kontekstual, guru dalam pembelajarannya mengaitkan antara materi yang akan diajarkannya dengan dunia nyata siswa dan mendorong siswa membuat hubungan antara pengetahuan yang dimiliki dengan penerapannya dalam kehidupan mereka sehari-hari, dengan melibatkan tujuh komponen utama CTL yakni ( Dit. PLP, 2003: 10):

1. Berfilosofi

konstruktivisme (Contructivism)

Pembelajaran yang berciri konstruktivisme menekankan terbangunnya pemahaman sendiri secara aktif, kreatif, dan produktif berdasarkan pengetahuan dan pengetahuan terdahulu dan dari pengalaman belajar yang bermakna. Pengetahuan bukanlah serangkaian fakta, konsep, dan kaidah yang siap dipraktekkannya. Manusia harus mengkonstruksinya terlebih dahulu pengetahuan tersebut dan memberikan makna melalui pengalaman nyata. Karena itu siswa perlu dibiasakan untuk memecahkan masalah, menemukan sesuatu yang berguna bagi dirinya, dan mengembangkan ide-ide yang ada pada dirinya.

2. Mengutamakan kegiatan menyelidiki (Inquiry) 
Komponen menemukan merupakan kegiatan inti CTL. Kegiatan ini diawali dari pengamatan terhadap fenomena, dilanjutkan dengan kegiatan-kegiatan bermakna untuk menghasilkan temuan yang diperoleh sendiri oleh siswa. Dengan demikian, pengetahuan dan keterampilan yang diperoleh siswa tidak dari hasil mengingat seperangkat fakta yang dihadapinya.

3. Mengutamakan terjadinya kegiatan bertanya (Questioning)

Komponen ini merupakan strategi pembelajaran CTL. Belajar dalam pembelajaran CTL dipandang sebagai upaya guru yang bisa mendorong siswa untuk mengetahui sesuatu, mengarahkan siswa untuk memperoleh informasi, sekaligus mengetahui perkembangan kemampuan berpikir siswa. Pada sisi lain, kenyataan menunjukkan bahwa pengetahuan seseorang selalu diperoleh bermula dari bertanya.

4. Menciptakan masyarakat belajar (Learning Community)

Konsep ini menyarankan bahwa hasil belajar sebaiknya diperoleh dari kerja sama dengan orang lain. Hal ini berarti bahwa hasil belajar bisa diperoleh dengan sharing antarteman, antarkelompok, dan antara yang tahu kepada yang tidak tahu, baik di dalam maupun di luar kelas. Di kelas melalui komunikasi dua arah antara guru dan siswa atau antara siswa dan siswa

5. Ada pemodelan (Modeling)

Komponen ini menyarankan bahwa pembelajaran keterampilan dan pengetahuan tertentu diikuti dengan model yang bisa ditiru siswa. Model yang dimaksud bisa berupa pemberian contoh tentang misalnya cara mengoperasikan sesuatu, menunjukkan hasil karya, mempertontonkan suatu penampilan. Cara pembelajaran semacam ini akan lebih cepat dipahami siswa daripada hanya bercerita atau memberikan penjelasan kepada siswa tanpa ditunjukkan modelnya atau contohnya

\section{Ada refleksi (Reflection)}

Komponen yang merupakan bagian terpenting dari CTL adalah perenungan kembali atas pengetahuan yang baru dipelajari, menelaah dan merespons semua kejadian, aktivitas, atau pengalaman yang terjadi dalam pembelajaran, bahkan memberikan masukan atau saran jika diperlukan, siswa akan menyadari bahwa pengetahuan yang baru diperolehnya merupakan pengayaan bahkan revisi dari pengetahuan yang telah dimiliki sebelumnya. Kesadaran semacam ini penting ditanamkan kepada siswa agar ia bersikap terbuka terhadap pengetahuanpengetahuan baru.

7. Penilaian pembelajarannya autentik (Authentic Assesment)

Komponen ini merupakan proses pengumpulan berbagai data yang bisa memberikan gambaran atau informasi terhadap perkembangan pengalaman belajar siswa. Dengan demikian penilaian autentik diarahkan pada proses mengamati, menganalisis, dan menafsirkan data yang telah terkumpul ketika atau dalam proses pembelajaran 
siswa berlangsung. Sehingga penilaian yang berpijak pada hasil belajar nyata yang dapat dilakukan siswa yang mencakup penilaian terhadap kemajuan (proses) dan hasil belajar.

Teori kontruktivisme menyatakan bahwa untuk mendapatkan pemahaman yang mendalam membutuhkan metode pembelajaran yang memberi ruang siswa untuk melakukan investigasi secara bebas, dalam kondisi realistik dan konteks yang penuh makna. Hal ini melibatkan dua syarat yaitu investigasi personal dan konteks yang kompleks dan penuh makna. Ada lima fitur utama yang muncul dari penggunaan konteks dalam proses mengajar dan evaluasi, yaitu signifikansipraktis, kompleksitas dan tantangan, relevansi dan motivasi, kerkaitan dan transfer, serta pemberdayaan siswa (Libman, 2010). Berikut ini terdapat tiga ciri khas dalam pembelajaran kontekstualuntuk statistika yaitu:

1. Titik awal proses pembelajaran merupakan penggunaan masalah berkonteks kehidupan nyata (kontekstual) yang konkret atau yang ada dalam alam pemikiran siswa. Masalah-masalah yang ada dapat disajikan dengan cerita, lambang, model, atau gambar. Dalam hal ini siswa diharapkan dapat menemukan alat statistis atau model statistis sekaligus memahmai konsep atau prinsipnya.

2. Pembelajaran ini menghindari cara mekanik yaitu berfokus pada prosedur penyelesaian soal. Meskipun begitu belum sepenuhnya dapat diterpakan karena belum dapat dihilangkan, sehingga dalam pelaksanaannya masih dijumpai meskipun tidak dominan. Siswa diharapkan dapat menemukan alat atau model statistis untuk dapat menyelesaikan masalah.

3. Siswa diperlakukan sebagai peserta aktif dengan diberi keleluasaan menemukan sendiri atau mengembangkan alat, model dan pemahaman statistis melalui penemuan dengan bantuan guruatau diskusi bersama teman. Kegiatan pembelajaran ini dapat dilakukan dengan diskusi kelompok antara siswa dengan orang dewasa atau dengan teman sebaya. Interaksi tersebut dapat diakomodasikan melalui belajar dalam kelompok heterogen (kelompok kooperatif yang beranggotakan 2-6 orang). Menurut Slavin, hal inni dapat mengakibatkan siswa yang berkemampuan "lemah" dapat belajar dari pemikiran teman sebayanya yang berkemampuan "lebih"sehingga belajar akan terasa mudah.

\section{Penutup}

Pembelajaran kontekstual (Contextual Teaching and Learning) adalah konsep belajar yang menghadirkan dunia nyata ke dalam kelas dan mendorong siswa membuat hubungan antara pengetahuan yang dimilikinya dengan penerapannya 
dalam kehidupan sehari-hari, siswa memperoleh pengetahuan dan keterampilan dari konteks, dan dari proses mengkonstruksi sendiri sebagai bekal untuk memecahkan masalah dalam kehidupannya sebagai anggota masyarakat. Pembelajaran statistika dengan pendekatan kontekstual dimana siswa didorong untuk mengaitkan materi statistika yang dipelajari dalam kehidupan nyata siswa sehari-hari, baik di lingkungan keluarga, sekolah atau masyarakat dengan tujuan untuk menemukan makna materi tersebut bagi kehidupannya.

\section{Daftar Pustaka}

Dasari, D. (2009). Meningkatkan Kemampuan Penalaran Statistis Mahasiswa Melalui Pembelajaran Model PACE. Disertasi SPS UPI, tidak diterbitkan.

Delmas et al. (2001). Validating Types of Reasoning about Sampling Distribution. Presentation at The Second International Research Forum on Statistical Reasoning, Thinking and Literacy, Armidale, Australia.

Dirjen Pendidikan Lanjutan Pertama, (2003). Pendekatan Contextual Teaching and Learning (CTL). Jakarta: Departemen Pendidikan Nasional Dirjen Dikdasmen.

Garfield, J. \& Chance, B. (2000). Assesment in Statisyics Issues and Challenges. Mathematical Thinking and Learning. 2,99-125.

Garfield, J. (2002). The Challenge of Developing Statistical Reasoning.
Journal of Statistics Education Volume 10, Number 3.[on line], 10 (3).www.amstst.org/publications/jse/ 10v3/garfield.html. [8 November 2016].

Garfield, J. Dan Ben-Zvi, D. (2004). Statistical Literacy, Reasoning, And Thinking: Goals, Defenitions, And Challeges. In D. Ben-Zvi \& Garfield (Eds). The Netherland: Kluwer Academic Publishers.

Johnshon, E.B.(2002). Contextual Teaching and learning. California: CROWIN PRESS, INC.

Libman, Z. (2010). Integrating RealLifedata Analysisin Teaching Descriptive Statistics: A. Contructivist Approch. Journal of Statistics Education, 18(1).

Lovett, M. (2001). A Collaborative Convergence On Studyng Reasoning Procesess: A Case Study In Statistics. In D. Khair \& S. Cerver (Eds), Cognition And Instrucion: Twenty-Five of Progress (Pp. 347-384). Mahwah, NJ: Lawrence Erlbaun.

Nur, M.,\& Wikandari, P.R.(2000). Pengajaran Berpusat kepada Siswa dan Pendekatan Kontruktivis dalam Pengajaran. Surabaya : Pusat Studi Mattematika dan IPA Sekolah. Universitas Negeri Surabaya.

Nurhadi.(2002). Pendekatan Kontekstual (Contextual Teaching and Learning/ CTL). Jakarta: Departemen Pendidikan Nasional, Dirjen Dikdasmen, Dirjen Pendidikan Lanjutan Pertama. 
Olani et al. (2011). Statistical Reasoning Abiliy, Self-Eficacy, And Value Beliefs In A Reform Based University Statistics Course. The Netherland Institute For Educational Research, University Of Groningen.

Rosman, A.M. \& Chance, B.L. (2001). Workshop Statistics: Discovery with Data, New York: Springer Verlag.

\section{Riwayat Hidup PenUlis}

lyam Maryati, M.Pd.

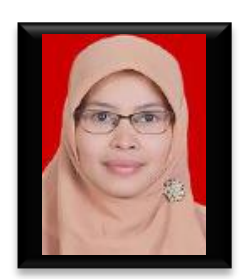

Staf pengajar di STKIP Garut. Studi S2 Pendidikan Matematika Universitas Pasundan, Bandung; dan S3 Pendidikan Matematika Universitas Pendidikan dengan sekarang. Indonesia, Bandung, sampai 